\title{
Psychologiczne i prawne aspekty kontaktów osadzonych ojców z dziećmi
}

\author{
KATARZYNA JADACH \\ ORCID: 0000-0002-4875-6558 \\ Zakład Penitencjarystyki
}

Wydział Studiów Edukacyjnych Uniwersytetu im. Adama Mickiewicza w Poznaniu

\section{Magdalena SAdowsKa \\ ORCID: 0000-0002-4417-9503 \\ Zakład Penitencjarystyki}

Wydział Studiów Edukacyjnych Uniwersytetu im. Adama Mickiewicza w Poznaniu

\section{Wprowadzenie}

Aby wymiar sprawiedliwości owocnie i z korzyścią dla uwikłanych w procedury sądowe podmiotów prawa, czyli stron bądź uczestników postępowania, realizował przypisane mu zadania, musi być służebny — założenie to nabiera wagi, gdy orzecznicza aktywność zostanie zogniskowana wokół spraw rodzinnych i opiekuńczych. Analiza poszczególnych instytucji gałęzi prawa reprezentujących tego rodzaju stosunki prawne prowadzi do wniosku, że polski ustawodawca stara się nie zapominać o wpływie psychologii na prawo ${ }^{1}$. Kształtowaniu relacji między prawem

${ }^{1}$ Świadczą o tym między innymi obecność mediacji w sporach małżeńskich i rodzicielskich, możliwość zawarcia porozumienia rodzicielskiego w sytuacji rozwodowej i życia rodziców małoletniego dziecka w rozłączeniu, sposób ograniczenia władzy rodzicielskiej poprzez skierowanie rodziców na odpowiednią terapię, dążenie do zapoznania się przez sędziego ze stanowiskiem dziecka w ramach czynności wysłuchania oraz obo- 
a psychologią służą również klauzule generalne zajmujące w normach prawa rodzinnego niezwykle istotne miejsce. Chodzi zwłaszcza o zasady dobra dziecka, dobra rodziny, autonomii rodziny czy prymatu rodziców w wychowaniu dziecka, które umożliwiają sędziemu rodzinnemu adekwatne reagowanie na różnorodne sytuacje zachodzące w rodzinach. W poszczególnych regulacjach Kodeksu rodzinnego i opiekuńczego widoczny jest namysł ustawodawcy nad specyfiką spraw, dla których stanowi on materialne podstawy rozstrzygnięcia, dążenie do urzeczywistnienia zasady koncyliacyjności postępowań prawnych oraz baczenie na służebnościową względem rodziny rolę wymiaru sprawiedliwości.

Realizacja założeń takiego modelu napotyka przeszkody w sytuacji, gdy jeden z członków rodziny naruszy porządek prawny, stając się w konsekwencji sprawcą przestępstwa. Uruchomienie reakcji karnoprawnej w postaci skazania na karę pozbawienia wolności jest dowodem realizowania funkcji sprawiedliwościowej w trybach procesu karnego. Dla nauki prawa karnego funkcja ta ma fundamentalne znaczenie, choć także w wymiarze społecznym retrybucja odgrywa istotną rolę ochronną. Czy jednak fakt popełnienia czynu zabronionego i bycia skazanym prawomocnym wyrokiem na izolację w warunkach zakładu penitencjarnego sprawia, że wobec takiej osoby ustawowa gwarancja ochrony stosunków rodzinnych przestaje obowiązywać? W niniejszym tekście podjęta została próba charakterystyki sytuacji osadzonych ojców z uwzględnieniem aspektów prawnych i psychologicznych w kontekście realizacji ich prawa do kontaktów z dziećmi².

wiązek takiego wysłuchania spoczywający na rodzicach podejmujących decyzje w istotnych sprawach dziecka itp. Zob. M. Andrzejewski, Standardy opiniowania psychologicznego w sprawach rodzinnych i opiekuńczych - komentarz prawny, [w:] Standardy opiniowania psychologicznego w sprawach rodzinnych i opiekuńczych, red. A. Czerederecka, Kraków 2016, s. 135-136.

${ }^{2} \mathrm{~W}$ artykule skupiono się na instytucji kontaktów z dzieckiem, pomijając o wiele bardziej złożoną problematykę statusu prawnego osadzonych sprawujących opiekę nad dziećmi. Na ten temat wypowiedzieli się między innymi: A. Kwieciński, Skazani-rodzice. Sytuacja prawna osadzonych sprawujących opiekę nad dziećmi, „Nowa Kodyfikacja Prawa Karnego" 28, 2012, s. 187-202; oraz A. Kilińska-Pękacz, Prawo rodziców osób osadzonych do opieki $i$ wychowania dzieci, „Przegląd Więziennictwa Polskiego” 2018, nr 99, s. 55-78. W artykule nie odniesiono się również do problematyki postępowania sądowego w sprawie o uregulowanie kontaktów, która nabiera szczególnego znaczenia 


\section{Psychologiczne aspekty sytuacji osadzenia}

Kontakty uwięzionych rodziców z dziećmi mają bardzo duże znaczenie dla zdrowia psychicznego obu stron. Rodzina jest grupą, w ramach której w pierwszych latach życia młodego człowieka dochodzi do jego rozwoju emocjonalnego, społecznego, moralnego, fizycznego, a nabyte w dzieciństwie wzorce stają się kapitałem na całe późniejsze życie jednostki. Sytuacja, w której jeden z rodziców opuszcza rodzinę, nawet tymczasowo, powoduje zachwianie dotychczasowego funkcjonowania pozostałych jej członków i wkłada na ich barki dodatkowe obciążenie. W sytuacji izolacji penitencjarnej uwięziony rodzic nie ma wielu możliwości codziennego nadrabiania swojej nieobecności w domu, choć pewnych szans można upatrywać w częstych kontaktach z najbliższymi. Są one istotne, gdyż zaniedbane w dzieciństwie oddziałują na społeczne i emocjonalne funkcjonowanie człowieka dorosłego.

Jak wynika z danych gromadzonych przez Służbę Więzienną, 31 sierpnia 2019 roku w polskich zakładach karnych oraz aresztach śledczych przebywało 73577 osób tymczasowo aresztowanych i skazanych, w tym 3139 kobiet i 70438 mężczyzn ${ }^{3}$. Wśród osadzonych mężczyzn znajdują się ojcowie, którzy za pośrednictwem dostępnych środków, uczestnicząc w programach prowadzonych przez Służbę Więzienną, w zależności od własnego zaangażowania, dążą do utrzymywania relacji z dziećmi.

W polskiej literaturze znajdują się opracowania, które wskazują na liczne psychologiczne konsekwencje wynikające z braku lub ograniczenia kontaktu między uwięzionymi rodzicami a ich dziećmi. Zjawisko zniszczenia lub rozluźnienia dotychczasowych relacji między jednostką a jej otoczeniem społecznym nazywane jest izolacją (penitencjarna nie jest tu wyjątkiem $)^{4}$. Niszczącemu wpływowi izolacji ulegają między innymi relacje skazany ojciec-dziecko, a ich rozpad może wywołać różne

w sytuacji konfliktu pomiędzy rodzicami, stanowiącego częste tło działalności diagnostycznej zespołów sądowych specjalistów. Zob. A. Czerederecka, Rozstrzyganie o kwestiach zwiazanych ze sprawowaniem władzy rodzicielskiej i uregulowaniem kontaktów z dziećmi - refleksje psychologa, ,Rodzina i Prawo” 2013, nr 26-27, s. 97-98.

3 www.sw.gov.pl (dostęp: 3.10.2019).

${ }^{4}$ B. Waligóra, Funkcjonowanie człowieka w warunkach izolacji więziennej, Poznań 1974, s. 5. 
skutki natury psychologicznej zarówno u rodziców, jak i dzieci. Pomimo podejmowanych działań przez samych ojców, członków rodziny czy funkcjonariuszy Służby Więziennej w wyniku izolacji relacje osadzonych z dziećmi muszą ulec zmianie.

Monika Badowska-Hodyr objęła badaniami kontakty polskich i czeskich rodziców pozbawionych wolności z ich dziećmi poniżej 15. roku życia i zbadała ich wpływ na możliwość przeciwdziałania dolegliwościom kary oraz proces readaptacji społecznej, a także podjęła próbę oceny postaw rodzicielskich uwięzionych ${ }^{5}$. W celu psychologicznej analizy kontaktów rodziców z dziećmi (w tym ojców, których w badaniach autorki było 78, co stanowiło $41,7 \%$ badanej grupy) warto bliżej przyjrzeć się scharakteryzowanym w badaniach emocjom. W obszarze dolegliwości kary pozbawienia wolności najczęściej wskazywaną przez rodziców trudnością była utrata więzi z rodziną przy jednoczesnym uznawaniu posiadania osób najbliższych za największą wartość w życiu (wskazało tak 82,9\% rodziców polskich i 79,0\% rodziców czeskich). W grupie badanej przez M. Badowską-Chodyr utracie więzi z dziećmi towarzyszyły takie emocje i odczucia, jak: obniżony poziom nastroju (doświadczyło go $59,4 \%$ badanych), płaczliwość $(52,4 \%)$ oraz stany depresyjne $(38,0 \%)$. W sytuacji utrzymywania satysfakcjonującego kontaktu $54,5 \%$ badanych odczuwało radość z bezpośredniego kontaktu z dziećmi, 54\% czerpało ze spotkań z nimi siłę i wsparcie oraz odczuwało poczucie szczęścia 47,1\%. Jednocześnie bezpośrednie oraz pośrednie kontakty z dziećmi u 39\% badanych wywołują przygnębienie z powodu niemożności codziennego wypełniania roli rodzica, wzmacniają tęsknotę u 38\% przepytanych rodziców i potęgują wyrzuty sumienia z powodu dokonania przestępstwa u $38 \%$ matek i ojców.

Na podstawie analizy samych emocji ukazanych w badaniach autorka słusznie postuluje, aby ten ładunek emocjonalny wykorzystać do zmian w zachowaniu bądź osobowości osadzonych rodziców ${ }^{6}$. Proponuje, żeby indywidualne losy rodziców, przez wykorzystanie emocji towarzyszących kontaktom z dziećmi, stały się nauką dla synów i córek przekazywaną

5 M. Badowska-Hodyr, Rodzice i ich dzieci w przestrzeni penitencjarnej z perspektywy zasad indywidualizacji oraz procesu reintegracji społecznej, „Probacja” 2018, nr 1, s. $26 \mathrm{n}$.

6 Ibidem, s. 37. 
przez samych osadzonych. Wykorzystywanie wywołanych emocji czy też przekazywanie wzorów zachowania bądź własnych doświadczeń nie może jednak odbywać się bez kontaktów uwięzionych rodziców z dziećmi, najlepiej bezpośrednich. Omawiane badania pokazują również emocjonalne konsekwencje rozłąki rodziców z dziećmi, które uwidaczniają się w zachowaniu opiekunów. Oprócz już wymienionych: obniżonego nastroju, płaczliwości i depresji, rodzice zmagali się z apatią (16,6\% badanych), poczuciem straconych chwil $(23,5 \%)$, nadpobudliwością $(25,1 \%)$, agresją $(11,2 \%)$ i autoagresją $(2,1 \%)$ oraz zaburzeniami wegetatywnymi $(25,7 \%)$.

Ważnym psychologicznym aspektem kontaktów dzieci i rodziców, którzy odbywają karę pozbawienia wolności, jest motywacja. W literaturze można odnaleźć wyniki badań wskazujące, że podtrzymywanie więzi rodzica z dzieckiem sprzyja uzyskiwaniu pozytywnych efektów rozumianych jako wzrost motywacji do podejmowania działań na rzecz zmiany własnego zachowania skazanych. Anna Chańko-Kraszewska w badaniach poświęconych percepcji rodzin przez osoby pozbawione wolności wskazuje, że skazani ojcowie, jeśli sami nie są przekonani o skuteczności terapii uzależnień, decydują się na jej podjęcie ze względu na dziecko ${ }^{7}$.

W sytuacji uwięzienia rodzica emocje towarzyszą również dziecku. Kontakty z matką lub ojcem pozbawionymi wolności mogą zaostrzać lub łagodzić stany emocjonalne u pozostałych na wolności członków rodziny. Jak wskazuje Aneta Domżalska, skazanie rodzica na karę pozbawienia wolności wywołuje u dzieci głównie negatywne emocje ${ }^{8}$, które wynikają z niezrozumienia sytuacji bądź poczucia wstydu w związku z osadzeniem rodzica w zakładzie karnym. Charakteryzując te emocje i uczucia, autorka pisze o lęku wynikającym z braku informacji o miejscu pobytu rodzica i o obawie, że rodzic pozostający na wolności również je opuści. U starszych dzieci niewyjaśnienie im sytuacji może z kolei prowadzić do poczucia, że powody uwięzienia nigdy nie są jasne i każdy może zostać pozbawiony wolności. Dziecięcemu przeżywaniu utraty jednego z rodziców towarzyszą także takie emocje i zachowania, jak: złość, wstyd, smutek, zażenowanie (to ostatnie w sytuacji bycia narażonym na niewłaściwe reakcje innych ludzi

7 A. Chańko-Kraszewska, Rodzina w percepcji i ocenie osób odbywających karę pozbawienia wolności, „Resocjalizacja Polska” 2018, nr 15, s. 175.

${ }^{8}$ A. Domżalska, Dzieci rodziców pozbawionych wolności, „Forum Pedagogiczne UKW" 2011, nr 1, s. 218 n. 
W związku z uwięzieniem rodzica, bycia naznaczonym), niska samoocena, depresja, moczenie nocne, zaburzenia snu i łaknienia, poczucie winy i brak poczucia sensu życia czy labilność emocjonalna. Na podobne emocje towarzyszące dziecku, którego rodzic przebywa w izolacji penitencjarnej, wskazuje przywołana wcześniej M. Badowska-Hodyr. Autorka ta do wymienionych wcześniej trudności emocjonalnych i w zachowaniu dołącza te o charakterze psychosomatycznym (bóle brzucha, głowy, reakcje skórne), edukacyjnym (zaburzenia koncentracji, trudności w uczeniu się) i społecznym (wycofanie się z relacji, postawa nadmiernie opiekuńcza wobec rodzica pozostającego na wolności i innych członków rodziny) ${ }^{9}$.

\section{Instytucja kontaktów — uwagi ogólne}

Wprowadzenie do polskiego porządku prawnego instytucji ,kontaktów z dzieckiem" nastąpiło w 2008 roku ${ }^{10}$. Od 13 czerwca 2009 roku zaczęły obowiązywać przepisy zawarte w art. 113 oraz w art. 113.1-113.6 Kodeksu rodzinnego i opiekuńczego ${ }^{11}$ (dalej k.r.o.). Są one normatywną podstawą definiowania kontaktów, wywodzenia zasad ustalania kontaktów, wyodrębnienia katalogu osób uprawnionych i zobowiązanych do kontaktu z dzieckiem oraz ustanawiania ograniczeń, jakie w zakresie kontaktów może nałożyć sąd. Problematyka kontaktów z dzieckiem została umieszczona w odrębnym oddziale 3 rozdziału II — „Stosunki między rodzicami a dziećmi” — bezpośrednio po części kodeksu poświęconej problematyce władzy rodzicielskiej i pieczy zastępczej. Taki zabieg legislacyjny ma uzasadnienie w twierdzeniach części doktryny prawniczej, które można sprowadzić do ogólnej tezy, iż kontakty nie stanowią elementu władzy rodzicielskiej ${ }^{12}$.

9 M. Badowska-Hodyr, op. cit., s. 26 n.

${ }^{10} \mathrm{Z}$ chwilą wejścia w życie przepisów ustawy z dnia 6 listopada 2008 roku o zmianie ustawy — Kodeks rodzinny i opiekuńczy oraz niektórych innych ustaw (Dz.U. z 2008 r. Nr 220, poz. 1431).

11 Ustawa z dnia 25 lutego 1964 roku (tekst jedn. Dz.U. z 2017 r. poz. 682 ze zm.).

12 Na temat odrębnego charakteru kontaktów wypowiadali się między innymi: T. Smyczyński, Prawo rodzinne i opiekuńcze, Warszawa 1997, s 163; J. Ignatowicz, [w:] System prawa rodzinnego i opiekuńczego, red. J.S. Piątkowski, Wrocław 1985, s 870; W. Stojanowska, Rozwód a dobro dziecka, Warszawa 1979, s. 182. Podobne stanowisko na gruncie 
Na gruncie wcześniej obowiązującego stanu prawnego (w brzmieniu obowiązującym przed 13 czerwca 2009 roku) nie funkcjonował w k.r.o. przepis, z którego jednoznacznie wynikałby odrębny byt prawa do osobistej styczności. Taki wniosek można było wysnuć, wnioskując a contrario przy wykładni art. $113 \S 1$, z którego wynikał obowiązek sądu opiekuńczego zakazania rodzicom pozbawionym władzy rodzicielskiej kontaktów z dzieckiem. Brak kontaktów nie był nieuniknioną konsekwencją ingerowania w rodzicielskie władztwo — sąd musiał nad tym zagadnieniem odrębnie się pochylić. Prawo do osobistej styczności z dzieckiem przysługiwało więc mimo pozbawienia rodzica władzy rodzicielskiej, jej zawieszenia lub ograniczenia, a także w sytuacji, gdy władza ta nie przysługiwała ojcu, ponieważ sąd nie przyznał mu jej w wyroku ustalającym ojcostwo ${ }^{13}$. W wyjątkowych okolicznościach, jeżeli wymagało tego dobro dziecka, sąd opierając się na dawnym brzmieniu art. 113 § 1 i 2, mógł ograniczyć lub zakazać kontaktów z dzieckiem, przy czym tego typu ingerencja sądu nie dotyczyła sytuacji rozwodowych i separacyjnych ani też faktycznego życia rodziców w rozłączeniu (regulowanych art. 58 i $107 \mathrm{w}$ dawnym brzmieniu).

Nowelizacja przepisów k.r.o. wiązała się ze zmianą w obszarze terminologii, albowiem dotychczas funkcjonujący zwrot „osobista styczność"14 (o którym mowa była w art. 113 w jego dawnym brzmieniu) został zastąpiony pojęciem ,kontakty”. Aktualne nazewnictwo obejmuje

poprzedniego stanu prawnego przyjmował Sąd Najwyższy, czego wyrazem jest między innymi uchwała pełnego składu Izby Cywilnej Sądu Najwyższego z dnia 18 marca 1968 roku, III CZP 70/66, OSNCP 1968, z. 5, poz. 77. O problemach związanych z wyodrębnieniem kontaktów (prawa do osobistej styczności) z zakresu władzy rodzicielskiej pisał T. Sokołowski, Charakter prawny osobistej styczności rodziców z dzieckiem, „Kwartalnik Prawa Prywatnego" 2000, z. 2.

13 Por. A. Gałakan-Halicka, Kontakty z dzieckiem $w$ świetle nowelizacji kodeksu rodzinnego i opiekuńczego z 6 listopada 2008 r., [w:] Kodeks rodzinny i opiekuńczy po nowelizacji, red. J. Mazurkiewicz, Wrocław 2010, s. 13-14; J. Ignatowicz, M. Nazar, Prawo rodzinne, Warszawa 2005, s. 311.

${ }^{14} \mathrm{Na}$ gruncie dawnych przepisów zauważalna w doktrynie była tendencja do używania zamiennie pojęć „,osobista styczność” i „kontakty”, przy czym zakresem znaczeniowym kodeksowego terminu obejmowano wiele sytuacji kontaktowania się z dzieckiem (były to — oprócz osobistych kontaktów, takich jak spotkania, odwiedziny, rozmowy — kontakty o charakterze pośrednim, do których zaliczano korespondencję tradycyjną i elektroniczną, rozmowy telefoniczne, zasięganie informacji o dziecku od osoby trzeciej). 
zakresem większą liczbę sposobów obcowania między osobami bliskimi. Można wśród nich wyróżnić osobistą styczność (przebywanie z dzieckiem, w tym odwiedziny, spotkania, zabieranie dziecka poza miejsce jego stałego pobytu oraz porozumiewanie się) i wiele sytuacji składających się na kontakty pośrednie (utrzymywanie korespondencji, korzystanie z innych środków porozumiewania się na odległość, w tym ze środków komunikacji elektronicznej). Są one bardzo różnorodne, co utrudnia wspólną ich charakterystykę, o czym świadczy nieobecność w k.r.o. ustawowej definicji nowej instytucji (w art. $113 \S 1$ mowa jest jedynie o jej prawnym charakterze jako uprawnieniu a zarazem obowiązku).

Treść oddziału 3 k.r.o. dowodzi podjęcia próby kompleksowego uregulowania kontaktów rodziców i innych osób bliskich z dziećmi. W poszczególnych jego przepisach zawarto bowiem: ogólną charakterystykę kontaktów (art. $113 \S 1$ ); egzemplifikacje bezpośrednich oraz pośrednich form kontaktów (art. 113 § 2); ideę koncyliacji, która może pomóc w należytym ustalaniu kontaktów w wypadkach, gdy dziecko nie mieszka stale $\mathrm{z}$ obojgiem rodziców, a także gdy nie przebywa u żadnego z rodziców, a pieczę nad nim sprawuje opiekun lub gdy zostało umieszczone w pieczy zastępczej (art. 113.1); przesłanki i sposoby ograniczenia kontaktów z dzieckiem (art. 113.2); normatywną podstawę orzeczenia zakazu utrzymywania kontaktów (art. 113.3). Ponadto w wyniku nowelizacji sądy zyskały dodatkową możliwość zobowiązywania rodziców do określonego postępowania (art. 113.4), co stanowi szczególną formę ograniczenia prawa do kontaktów z intencją udzielenia całej rodzinie pomocy specjalistycznej, w szczególności w zakresie terapii i poradnictwa; wreszcie uregulowano zagadnienie zmiany sposobu kontaktów, które były przedmiotem wcześniejszego rozstrzygnięcia (art. 113.5).

Przepisy k.r.o. o kontaktach są dostosowane do standardów międzynarodowych ${ }^{15}$ określonych w szczególności w Konwencji o prawach dziecka $^{16}$ (art. 9 i 10) oraz Europejskiej konwencji w sprawie kontaktów

15 Analizy rozwiązań kodeksowych w świetle standardów wynikających z dokumentów ponad- i międzynarodowych dokonała A.N. Schulz, Kontakty z dzieckiem, kontakty dziecka - nowelizacja kodeksu rodzinnego i opiekuńczego w świetle standardów europejskich, [w:] Kodeks rodzinny i opiekuńczy..., s. 73 n.

16 Konwencja została przyjęta przez Zgromadzenie Ogólne ONZ w dniu 20 listopada 1989 roku, a ratyfikowana przez Polskę w dniu 30 kwietnia 1991 roku (Dz.U. z 1991 r. Nr 120, poz. 526). 
z dziećmi ${ }^{17}$. Warto jednak zauważyć, że konwencja z 2003 roku posługuje się pojęciem „kontakt” w rozumieniu prawa dziecka i rodzica (ewentualnie innej osoby mającej z dzieckiem związki rodzinne), z którym ono stale nie mieszka, do uzyskania i utrzymywania z sobą regularnych kontaktów. Realizacja tego prawa powinna odbywać się w następujących formach: 1. pobytu dziecka przez określony czas albo jego spotkania z rodzicem lub inną osobą mającą rodzinne związki z dzieckiem; 2. każdej formie komunikacji między dzieckiem a taką osobą; 3. dostarczania takiej osobie informacji o dziecku albo dziecku o tej osobie.

Z zestawienia przytoczonej charakterystyki kontaktów z określeniem kodeksowym wynika, że przepisy k.r.o. nie są prostym przejęciem postanowień konwencji, gdyż uregulowano je jako złożoną sytuację prawną, na którą składają się zarówno prawa, jak i obowiązki podmiotów w nią zaangażowanych. Niezależnie skonstruowano też listę osób uprawnionych i zobowiązanych do kontaktów (oprócz innych osób bliskich wymienionych w art. 113.6 są to przede wszystkim rodzice, zarówno stale mieszkający z dzieckiem, jak i nie). Ponadto stworzono otwarty katalog form kontaktowania się. Nie można więc mówić o powielaniu w k.r.o. treści norm rangi międzynarodowej, a raczej o oryginalnej konstrukcji, której modelowy kształt należy odtwarzać, opierając się na literalnej wykładni poświęconych jej zapisów ustawowych. Są to w szczególności przywołane wcześniej przepisy materialne i regulujące formalną stronę aktywności podmiotów wchodzących w ten stosunek prawny oraz orzekającego w ich sprawie sądu ${ }^{18}$.

\section{Instytucja kontaktów w warunkach zakładu karnego}

Kontakty rodzica z dzieckiem w warunkach zakładu karnego wiążą się z problematyką wykonywania kary pozbawienia wolności. Kodeks

17 Konwencja z dnia 15 maja 2003 roku, sporządzona w Strasburgu (zob. thumaczenie na internetowej stronie Senatu: ww2.senat.pl/k7/dok/sejm/021/895.pdf, dostęp: 20.11.2019). Pomimo uchwalenia ustawy ratyfikującej nie doszło jednak w Polsce do skutecznej ratyfikacji tej Konwencji.

18 Chodzi przede wszystkim o art. 582.1 i art. 598.15-598.22 ustawy z dnia 17 listopada 1964 roku Kodeks postępowania cywilnego (tekst jedn. Dz.U. z 2018 r. poz. 1360 ze zm.). 
karny wykonawczy ${ }^{19}$ (dalej: k.k.w.) nie odnosi się w sposób bezpośredni do instytucji prawa rodzinnego, jednak na podstawie poszczególnych jego uregulowań można podjąć próbę ustalenia formy realizacji tego podstawowego dla stosunków rodzinnych uprawnienia. Podkreślenia wymaga jednak specyficzny charakter okoliczności, w jakich dochodzi do kontaktów między osadzonym a członkami jego rodziny. Z definicji kara pozbawienia wolności polega na odizolowaniu skazanego od społeczeństwa przez umieszczenie go w odpowiednim zakładzie karnym i tym samym pozbawienie go swobody wyboru miejsca pobytu i niezależności poruszania się $^{20}$. Jako kara kryminalna pozbawienie wolności zawiera więc w sobie dolegliwość, która z punktu widzenia ważnych społecznie wartości uderza w dobro podstawowe w postaci wolności fizycznej ${ }^{21}$. Ingerencja w nią wyraża się przede wszystkim w: całkowitej zależności skazanego od innych osób, uregulowanym czasie dnia, ograniczonej możliwości gospodarowania wolnym czasem, narzuconej dyscyplinie i przymusowej integracji środowiskowej ${ }^{22}$.

Utrzymywanie kontaktów z bliskimi w takich warunkach jest bardzo utrudnione, choć możliwe, a biorąc pod uwagę międzynarodowe gwarancje $^{23}$, wręcz pożądane. Również polski k.k.w. (art. $67 \S 1$ ), przyjmując za podstawowy cel wykonywania kary pozbawienia wolności prewencję szczególną ${ }^{24}$ - czyli kształtowanie społecznie pożądanej postawy skazanego i tym samym powstrzymanie go od powrotu do przestępstwa — jako jeden z podstawowych środków tak ukierunkowanego oddziaływania penitencjarnego wskazuje podtrzymywanie kontaktów z rodziną i światem zewnętrznym (art. 67 § 3). Jednocześnie należy pamiętać o treści art. 102, który konstruując otwarty katalog praw podmiotowych skazanego, na jednym z pierwszych miejsc (zaraz po zaspokojeniu potrzeb

19 Ustawa z dnia 6 czerwca 1997 roku (tekst jedn. Dz.U. z 2019 r. poz. 676 ze zm.).

20 E. Hryniewicz-Lach, Komentarz do art. 37, [w:] Kodeks karny. Czesśś ogólna. Komentarz do artykułów 1-116, red. M. Królikowski, R. Zawłocki, Lex/el 2017.

21 Pomijam tu doktrynalną dyskusję na temat terminologii kary i ustalenia jej semantyki (kara pozbawienia wolności rozumiana jako de facto ograniczenie wolności).

22 G.B. Szczygieł, Komentarz do rozdziału I \$ 4, [w:] System Prawa Karnego, t. 6. Kary i inne środki reakcji prawnokarnej, red. M. Melezini, Warszawa 2016, s. 228.

23 Zwłaszcza reguły 5, 6 i 24.1. Europejskich reguł więziennych oraz art. 8 europejskiej Konwencji o ochronie praw człowieka i podstawowych wolności.

24 S. Lelental, Kodeks karny wykonawczy. Komentarz, Warszawa 2017, s. 333. 
fizjologicznych, zapewnieniu dostępu do świadczeń zdrowotnych i warunków higieny) wskazuje prawo do utrzymywania więzi z rodziną i innymi osobami bliskimi. Jako narzędzie służące realizacji postulatywnych celów resocjalizacyjnych z jednej strony, a zarazem jako podstawowe prawo skazanego z drugiej, kontakty z rodziną i bliskimi jawią się jako uniwersalny standard, na straży utrzymania którego stają przepisy polskiego prawa wykonawczego.

W ten sposób ochrona stosunków rodzinnoprawnych opisanych w k.r.o. znajduje swoją systemową kontynuację. Ma ona jednak charakter szczególny, co wynika ze specyfiki środowiska zamkniętego. Należy zgodzić się $\mathrm{z}$ reprezentowanym w literaturze przedmiotu poglądem, iż przy charakterystyce środków i metod oddziaływania penitencjarnego trzeba pamiętać o podstawie ich uruchomienia, czyli skazaniu za popełnione przestępstwo. Osadzenie w zakładzie karnym stanowi karę, której dolegliwość wyraża się między innymi w koniecznej modyfikacji kontaktów ze środowiskiem zewnętrznym. Oczywiste jest, że nie będą one dowolne i nieograniczone, jednak intensywność modyfikacji (składająca się na stopień odczuwanej przez osadzonego dolegliwości) zależy od systemu wykonywania kary, rodzaju i typu zakładu oraz zaszeregowania sprawcy do określonej kategorii skazanych $^{25}$. Z punktu widzenia zakładanej przez ustawodawcę prewencji, zarówno w wymiarze generalnym, jak i indywidualnym, ustanowione w przepisach wykonawczych (k.k.w., rozporządzeniu Ministra Sprawiedliwości z dnia 21 grudnia 2016 roku w sprawie regulaminu organizacyjno-porządkowego wykonywania kary pozbawienia wolności ${ }^{26}$ — dalej: RegWykKPWR — oraz regulaminach i zarządzeniach obowiązujących na terenie poszczególnych jednostek penitencjarnych) limity w zakresie kontaktowania się z osobami z zewnątrz umożliwiają realizację negatywnych funkcji kary izolacyjnej ${ }^{27}$. Pogląd ten doskonale oddaje teza zawarta w wyroku Sądu Apelacyjnego w Warszawie o następującym brzmieniu:

25 Ibidem, s. 336.

${ }^{26}$ Dz.U. z 2016 r. poz. 2231.

${ }^{27}$ Chodzi przede wszystkim o rozmowy telefoniczne: art. 90 pkt 9, art. 91 pkt 11, art. 92 pkt 14, art. 105 b, art. $138 \S 1$ pkt 15, art. $242 \S 10$ k.k.w., $\S 14$ ust. 2 pkt 11 Reg WykKPWR; korespondencję: art. 90 pkt 8, art. 91 pkt 10, art. 105, art. 110a § 1, art. 242 $\S 6$ k.k.w. oraz $\S 14$ ust. 2 pkt 13 RegWykKPWR; widzenia: art. 88 b pkt 8 i 9, art. 90 pkt 6, art. 91 pkt 8, art. 91a, art. 92 pkt 10, art. 105a, art. $124 \S 3$, art. 138 § 1 pkt 1-3 i 7, 
Odbywając karę pozbawienia wolności, każdy osadzony powinien liczyć się z tym, że jest to kara odbywana w warunkach nie zawsze oczekiwanych przez skazanego, powiązana $\mathrm{z}$ dolegliwościami, utrudnieniami, a także ograniczeniami, często trudnymi do zaakceptowania, taki bowiem jest i powinien być jej charakter ${ }^{28}$.

Przechodząc do rozważań nad sposobem implikacji instytucji kontaktów z dziećmi w warunkach zakładu penitencjarnego, w pierwszej kolejności należy zaznaczyć, iż ich realizacja odbywa się w ramach ogólnego uprawnienia skazanego do utrzymywania więzi z rodziną i innymi osobami bliskimi. W świetle powyższego kontaktowanie się osadzonych z dziećmi stanowi szczególny rodzaj kontaktu ze światem zewnętrznym, przy czym o ile w wypadku podmiotów innego typu (małżonka, rodziców, rodzeństwa, innych członków rodziny, innych osób bliskich bądź podmiotów, na przykład pełnomocników, przedstawicieli organizacji społecznych czy organów państwowych) wchodzenie z nimi w bezpośrednie bądź pośrednie interakcje opiera się wyłącznie na zasadzie dobrowolności, o tyle — mając na uwadze treść art. $113 \S 1$ k.r.o. kontakty z dzieckiem są już nie tylko prawem, lecz przede wszystkim obowiązkiem osadzonego rodzica. Powstaje w związku z tym pytanie o zasadność oraz sposób egzekwowania wykonywania tego obowiązku w przypadkach, gdy pomimo woli ze strony dziecka rodzic takiego kontaktu unika. Wydaje się, że dyskusyjność zarówno zagadnienia obligatoryjności utrzymywania kontaktów, jak i realizowanego w obecnym stanie prawnym egzekucyjno-przymuszającego modelu tej instytucji ${ }^{29}$ jest problemem złożonym i wymaga odrębnego rozważenia, co przekracza ramy niniejszego opracowania. Warto jednak nadmienić, że w kontekście rozważań nad procedurą egzekwowania ustawowo gwarantowanych

art. $143 \S 1$ pkt 6, art. $148 \S 4$, art. $247 \S 1-3$ k.k.w. oraz $\S 14$ ust. 2 pkt 10 i $\S 23$ Reg WykKPWR i $§ 5$ rozporządzenia Rady Ministrów z dnia 4 sierpnia 2010 roku w sprawie szczegółowego trybu działań funkcjonariuszy Służby Więziennej podczas wykonywania czynności służbowych (Dz.U. z 2010 r. Nr 147, poz. 984); przepustki: art. 91 pkt 7, art. 92 pkt 9, art. 138 § 1 pkt 7 i 8 k.k.w.

28 Wyrok SA w Warszawie z dnia 20 października 2016 roku, VI ACa 1245/15, Legalis 1618005 .

${ }^{29}$ W literaturze przedmiotu mowa jest także o modelu przyczynowo-skutkowym; zob. J. Ignaczewski, Komentarz do spraw o kontakty z dzieckiem i o ich wykonanie, [w:] Komentarz do spraw rodzinnych, red. J. Ignaczewski, Warszawa 2014, s. 148. 
praw (prawa do kontaktu) pojawia się wątek diagnostyczny związany $\mathrm{z}$ uruchomieniem opiniodawczych zespołów sądowych specjalistów ${ }^{30}$.

Kontakty z dziećmi realizowane są przez osadzonych w formie: przepustek, widzeń, rozmów telefonicznych oraz korespondencji. Częstotliwość korzystania z każdej z nich jest uzależniona - zgodnie z wcześniej poczynionymi uwagami — od woli samego osadzonego, jednak równie istotną przesłanką o charakterze formalnym jest rodzaj i typ zakładu karnego, w którym odbywa on karę $^{31}$. Rozmowy telefoniczne oraz korespondencja są formami kontaktów pośrednich, podlegają więc obostrzeniom jedynie w wypadkach przewidzianych w k.k.w. (kontrole rozmów telefonicznych i cenzurowanie treści korespondencji w zakładach typu półotwartego i zamkniętego), a pod względem organizacyjnym regulowane są aktami wewnętrznymi każdego zakładu karnego. Z kolei widzenia oraz przepustki pozwalają na kontakt bezpośredni, jednak ze względów bezpieczeństwa forma ta jest albo bardzo ograniczona w czasie (widzenia), albo zupełnie wykluczona (przepustki) ${ }^{32} \mathrm{w}$ wypadku osadzonych w zakładach typu zamkniętego. Największe możliwości w zakresie realizacji prawa do kontaktów mają osoby odbywające karę w zakładach typu otwartego, choć i oni muszą liczyć się z pewnymi obostrzeniami (w przypadku widzenia chodzi przede wszystkim o czas jego trwania, liczbę widzeń w ciągu dnia oraz liczbę osób uczestniczących w widzeniu; w wypadku przepustek ograniczeniem jest częstotliwość ich udzielania przez dyrektora w ciągu jednego miesiąca oraz długość trwania w skali jednego roku).

Zważywszy na formalno-organizacyjne utrudnienia, jakie napotykają skazani w realizacji prawa do kontaktu z dzieckiem, warto przypomnieć, iż z treści Konwencji w sprawie kontaktów z dziećmi (art. 2 pkt a) wynika, że jedną z jej form jest dostarczanie osobie uprawnionej informacji o dziecku albo dziecku o tej osobie. Co prawda polski k.r.o.

30 Orzekanie w sprawach dotyczących kontaktów wchodzi w zakres ustawowych zadań zespołów, co wynika z brzmienia art. 1 ust. 1 ustawy z dnia 5 sierpnia 2015 roku o opiniodawczych zespołach sądowych specjalistów (tekst jedn. Dz.U. z 2018 r. poz. 708).

31 Odniesienie do regulacji prawnych zawarto w przyp. 27.

32 Istnieje jednak możliwość przyznania osadzonemu w takim zakładzie nagrody w postaci zezwolenia na widzenie poza zakładem na okres do 30 godzin i zezwolenia na opuszczenie zakładu na okres do 14 dni (art. 138 § 1 pkt 7 i 8 k.k.w.). 
w art. $113 \S 2$ o tej formie nie wspomina, jednak zarówno w orzecznictwie, jak i doktrynie panuje zgodny pogląd, że prawo do informacji o dziecku jest częścią składową prawa do kontaktu ${ }^{33}$. Jest to najbardziej uniwersalny sposób kontaktowania się osadzonych z dziećmi, do którego przepisy karne wykonawcze nie odnoszą się wprost i którego realizacja może się odbywać różnorodnymi kanałami (również poprzez korespondencję i rozmowy telefoniczne). Co więcej, taka forma może się okazać podstawowa w wypadku skazanych, których więzi z dziećmi są słabe bądź — z uwagi na urodzenie się dziecka bezpośrednio przed lub w trakcie osadzenia — nie zdążyły się jeszcze wykształcić.

Przepisy prawa wykonawczego w sposób szczególny odnoszą się do sytuacji kontaktowania się osadzonego z dzieckiem w art. 87a oraz 105a k.k.w. Pierwszy z przywołanych przepisów można uznać za lex specialis W stosunku do ogólnie brzmiącego art. $67 \S 3$. W art. 87a $\S 1$ zawarty został nakaz adresowany do organów wykonujących karę pozbawienia wolności wobec skazanych sprawujących stałą pieczę nad dzieckiem do lat 15 uwzględniania w oddziaływaniach potrzeby inicjowania, podtrzymywania i zacieśniania ich więzi uczuciowej z dziećmi, wywiązywania się z obowiązków alimentacyjnych oraz świadczenia pomocy materialnej dzieciom, a także współdziałania z placówkami opiekuńczo-wychowawczymi, w których te dzieci przebywają. Z kolei § 2 zawiera dyspozycję osadzania „w miarę możliwości” skazanych sprawujących stałą pieczę nad dziećmi przebywającymi w placówkach opiekuńczo-wychowawczych w zakładach karnych położnych w miejscu pobytu dzieci. Nakaz podejmowania działań wspierających stosunki rodziców z dziećmi przyjmuje postać szerokiej formuły prowadzenia w obrębie zakładu karnego pracy edukacyjnej oraz współdziałania z innymi podmiotami (na przykład zakładami pracy, jednostkami pomocy społecznej) w celu umożliwienia wywiązywania się skazanych z obowiązków alimentacyjnych i uzyskiwania przez dzieci świadczeń materialnych.

Wątpliwości interpretacyjne może budzić przywołany w przepisie zwrot „stała piecza nad dzieckiem”, który ma odróżnić tę kategorię skazanych rodziców od innych. W przepisach k.r.o. pojęcie „stała piecza”

33 Wynika to przede wszystkim z otwartego katalogu elementów składających się na pojęcie kontaktów z dzieckiem. 
nie funkcjonuje, w przeciwieństwie do ,pieczy nad osobą” (art. $95 \S 1$ ), która stanowi osobowy składnik władzy rodzicielskiej. Z założenia instytucja ta ma charakter stały, wykonywana jest bowiem (poza przypadkami interwencji sądowej) do momentu osiągnięcia przez dziecko pełnoletności (art. 92). Inaczej piecza ujmowana jest w okolicznościach pieczy zastępczej (na przykład gdy dziecko zostaje umieszczone w rodzinie zastępczej). Wówczas piecza sprawowana nad wychowankiem przyjmuje postać „pieczy bieżącej” (art. $112.1 \S 1$ ), rozumianej jako całokształt codziennych bezpośrednich czynności opiekuńczych związanych z zapewnieniem dziecku właściwych warunków egzystencji i rozwoju ${ }^{34}$. W innym miejscu k.r.o. ustawodawca posługuje się terminem „opieka”, obejmującym pieczę nad osobą i majątkiem pozostającego pod opieką (art. $155 \S 1$ ), zarezerwowanym dla wąsko rozumianej instytucji opieki prawnej. Zastosowany w art. 87a k.k.w. termin „stała piecza” nie znajduje więc swojego odpowiednika w przepisach prawa rodzinnego, co więcej — również k.k.w. posługuje się nim jednorazowo, bez wyraźnych wskazówek interpretacyjnych. Można jedynie, wspierając się wykładnią funkcjonalną, odczytać intencje ustawodawcy objęcia zakresem regulacji tego przepisu osoby sprawujące nad małoletnim do 15. roku życia władzę rodzicielską, ewentualnie opiekę prawną, z zastrzeżeniem, że $\mathrm{z}$ chwilą umieszczenia rodzica $\mathrm{w}$ jednostce penitencjarnej w celu wykonania kary długoterminowej termin „stała” w zasadzie się dezaktualizuje. W związku z powstałą nieścisłością powstaje oczekiwanie posługiwania się w przepisach karnych wykonawczych terminami, które na gruncie prawa rodzinnego mają swoje utrwalone znaczenie ${ }^{35}$.

$\mathrm{W}$ art. 87a $\S 2$ odwołano się do miejsca odbywania kary pozbawienia wolności, co dla jakości realizacji prawa do kontaktów ma fundamentalne znaczenie. Wskazana w przepisie preferencja w zakresie wyboru miejsca osadzenia (odpowiednie zakłady karne położone najbliżej miejsca pobytu dzieci) dotyczy wyłącznie sytuacji, gdy dzieci przebywają w placówkach opiekuńczo-wychowawczych. Pominąwszy wątpliwą kwestię sprawowania stałej pieczy nad dzieckiem, gdy przebywa

34 M. Safjan, Osamotnione dzieci. Rodziny zastępcze i rodzinne domy dziecka, Warszawa 1983, s. 44.

35 Na powstałą terminologiczną nieścisłość zwracano już uwagę w literaturze przedmiotu; zob. A. Kwieciński, op. cit., s. 197. 
ono pod pieczą instytucjonalną, należy podkreślić instrukcyjny charakter sformułowania „w miarę możliwości”, co stawia pod znakiem zapytania jego gwarancyjność. Problematyka kierowania skazanych do jednostek penitencjarnych, w których mają odbywać karę, jest przedmiotem regulacji art. $100 \S 1$ k.k.w. Zgodnie z brzmieniem tego paragrafu kara odbywana jest w zakładzie karnym właściwym ze względu na rodzaj, typ, system wykonywania kary lub zabezpieczenie, przy czym o doborze tym w procesie klasyfikacji decyduje komisja penitencjarna po przeprowadzeniu badań osobopoznawczych ( $\$ 52$ RegWykKPWR). Wśród kryteriów klasyfikacyjnych branych pod uwagę przy dokonywaniu rozpoznania wymienia się w szczególności: płeć, wiek, uprzednie odbywanie kary pozbawienia wolności, umyślność lub nieumyślność czynu, czas pozostałej do odbycia kary pozbawienia wolności, stan zdrowia fizycznego i psychicznego, w tym stopień uzależnienia od alkoholu, środków odurzających lub psychotropowych, stopień demoralizacji i zagrożenia społecznego oraz rodzaj popełnionego przestępstwa (art. 82 k.k.w. § 2).

Jest to co prawda katalog otwarty, jednak wskazuje on podstawowe elementy, które komisja bierze pod uwagę, wydając decyzję klasyfikacyjną. Oznacza to, że ustawodawca daje pierwszeństwo zasadzie indywidualizacji wykonywania kary pozbawienia wolności przed regułą, zgodnie z którą skazany powinien odbywać taką karę najbliżej miejsca swego zamieszkania (reguła 17.1. Europejskich reguł więziennych: „Więźniowie są osadzani, na ile to możliwe, w zakładach znajdujących się jak najbliżej ich domów lub miejsc resocjalizacji”) ${ }^{36}$. W przepisach wykonawczych nie wskazano natomiast właściwości miejscowej jednostek, w których wykonywana jest kara pozbawienia wolności, co oznacza, że skazany może być kierowany do jakiegokolwiek zakładu odpowiedniego ze względu na kryteria wskazane w art. 100 k.k.w. Konsekwencją takiej regulacji jest osadzanie skazanych w jednostkach na terenie całego kraju, niezależnie od miejsca stałego pobytu ich dzieci. Jedynie szeroko rozumiana przesłanka ,z ważnych względów rodzinnych” może uzasadniać decyzję dyrektora zakładu karnego o przeniesieniu skazanego do innego właściwego zakładu. W zasadzie jednak poza instrukcyjnie brzmiącym

36 J. Lachowski, Komentarz do art. 100, [w:] Kodeks karny wykonawczy. Komentarz, red. J. Lachowski, Warszawa 2018, s. 465. 
art. 87a $§ 2$ k.k.w. przepisy wykonawcze nie odnoszą się do miejsca odbywania przez skazanego rodzica kary pozbawienia wolności. Tym bardziej wspomniana nieprecyzyjność w zakresie ustawowych przesłanek zawartych w jedynym przepisie mającym stanowić gwarancję utrzymywania osadzonego z dzieckiem fizycznej bliskości jest uderzająca.

Szczególny sposób unormowania kontaktów osadzonych z dziećmi zawiera również art. 105a k.k.w. W § 2 tego przepisu w drodze wyjątku od zasady umożliwiono uczestnictwo nieograniczonej liczby niepełnoletnich osób ${ }^{37} \mathrm{w}$ widzeniu ze skazanymi. Jedynym warunkiem ich obecności na terenie jednostki penitencjarnej jest przebywanie w trakcie widzenia pod opieką osoby pełnoletniej, co ma zapobiegać negatywnym wpływom środowiska więziennego. Widzenia dzieci z osadzonymi rodzicami odbywają się pod nadzorem funkcjonariusza SW w pomieszczeniu przeznaczonym do tego celu dla wszystkich odwiedzających. Przepisy prawa wykonawczego gwarantują dzieciom i ich opiekunom wyłącznie odrębny stolik, co wskazuje na niekonsekwencję ustawodawcy, który w ramach toczących się procedur sądowych (cywilnych oraz karnych) podjął próbę wprowadzenia odrębnych trybów w sytuacjach, gdy w rolę świadka, uczestnika lub ofiary wchodzi osoba małoletnia ${ }^{38}$. Tworzeniu

${ }^{37}$ Przy aktualnym obciążeniu zadaniami zespołów orzekających jest to jednak jedynie rozwiązanie postulowane pro futura.

${ }^{38}$ Art. 185a i art. 185b ustawy z dnia 6 czerwca 1997 roku Kodeks postępowania karnego (tekst jedn. Dz.U. z 2018 r. poz. 1987 ze zm.). Pierwszy z przepisów określa szczególne warunki i tryb przesłuchiwania małoletnich pokrzywdzonych przestępstwami popełnionymi z użyciem przemocy lub groźby bezprawnej, przestępstwami przeciwko wolności, wolności seksualnej i obyczajności oraz przestępstwami przeciwko rodzinie i opiece. Z kolei w art. 185b określono szczególne warunki oraz tryb przesłuchiwania małoletnich świadków niebędących pokrzywdzonymi w sprawach dotyczących przestępstw popełnionych z użyciem przemocy lub groźby bezprawnej oraz przestępstw przeciwko wolności seksualnej i obyczajności, a także przestępstw przeciwko rodzinie i opiece. Szczegółowo problematykę sposobu przygotowania tego typu przesłuchan oraz warunków, jakim powinny odpowiadać pomieszczenia przesłuchań, reguluje rozporządzenie Ministra Sprawiedliwości z dnia 18 grudnia 2013 roku w sprawie sposobu przesłuchania przeprowadzanego w trybie określonym w art. 185a-185c Kodeksu postępowania karnego (Dz.U. z 2013 r. poz. 1642). Ratio legis wprowadzenia rozwiązań procesowych było przeciwdziałanie negatywnym oddziaływaniom toczącego się postępowania karnego na szczególnie wrażliwą psychikę dziecka. Z kolei w postępowaniach cywilnych na gruncie art. 430 funkcjonuje ogólny zakaz przesłuchiwania w charakterze świadków małoletnich, 
pokoi przesłuchań (tak zwanych przyjaznych pokoi) mających zapobiegać między innymi traumie obcowania $z$ wymiarem sprawiedliwości przyświecała intencja ochrony dobra dziecka. Niestety w momencie skazania rodzica fakt pobytu dziecka na terenie jednostki penitencjarnej jest w przepisach w zasadzie niezauważony ${ }^{39}$.

Niezależnie od materialnych uwarunkowań odbywających się widzeń rozważenia wymagałaby okoliczność pobytu w zakładzie karnym dziecka, który stwarza obawy o zagrożenie jego prawidłowego rozwoju. Wymagałoby to jednak wprowadzenia obowiązku informowania przez pracowników SW sądu rodzinnego o odbywających się kontaktach, przy których istnieje prawdopodobieństwo zagrożenia lub naruszenia dobra dziecka, co w dalszej kolejności mogłoby skutkować uruchomieniem postępowania diagnostycznego. Należy bowiem pamiętać, iż wyłącznym podmiotem stającym na straży interesu dziecka i weryfikującym jego gotowość emocjonalną oraz wolę bezpośredniego kontaktu z osadzonym rodzicem $\mathrm{w}$ formie widzeń na terenie jednostki penitencjarnej jest w zasadzie drugi rodzic, będący aktualnym lub byłym partnerem (małżonkiem) osadzonego. Odnosząc się z pełną powagą do naturalnego prymatu rodziców w kierowaniu dzieckiem i wychowywaniu go, nie sposób pozostać obojętnym wobec ustaleń poczynionych w ramach wewnątrzzakładowych badań osobopoznawczych. W wypadku niektórych skazanych w grupie uwarunkowań osobowościowych (zaburzenia psychiczne, osobowość aspołeczna) oraz środowiskowych (kariery przestępcze w rodzinie i związany z nimi mechanizm powielania, uzależnienie partnera od

którzy nie ukończyli 13 lat, a w wypadku zstępnych stron — małoletnich, którzy nie ukończyli 17 lat. Uzasadnieniem dla tego rozwiązania jest szczególnie intymny charakter spraw i dążenie do ochrony osób małoletnich przed angażowaniem ich w konflikty dorosłych. Sąd ma jednak możliwość dokonania informacyjnego wysłuchania dziecka (zarówno w postępowaniu procesowym na gruncie art. 216.1, jak i nieprocesowym, na gruncie art. $576 \S 2$ ), pod warunkiem że pozwala na to jego rozwój umysłowy, stan zdrowia oraz stopień dojrzałości. Wysłuchanie odbywa się poza salą posiedzeń, zazwyczaj w specjalnie do tego przygotowanych pomieszczeniach znajdujących się w budynku sądu.

${ }^{39}$ Przykładowo przepisy nie przewidują przeznaczania odrębnych dostosowanych również do potrzeb dzieci pomieszczeń na ich widzenia ze skazanymi rodzicami, co w aktualnych realiach funkcjonowania jednostek penitencjarnych mogłoby generować trudności natury organizacyjnej, jednak z pewnością bardziej zabezpieczałoby interes małoletnich. 
sprawcy przestępstwa przemocy w rodzinie) mogą występować czynniki przemawiające za wypełnieniem przez przedstawicieli SW obowiązków informacyjnych zgodnie z dyspozycją art. 572 k.p.c.

Komentowany przepis w $\S 3$ przyznaje skazanym, o których mowa $\mathrm{w}$ art. $87 \mathrm{a}$, prawo do dodatkowego widzenia z dziećmi. Poprzez odesłanie do nieprecyzyjnej — z uwagi na wspomniane określenie „stała piecza" - regulacji również art. 105a w tym fragmencie staje się niejasny. Powstają w związku z tym wątpliwości, jaka kategoria osadzonych ma zagwarantowane prawo do dodatkowego widzenia. Nie są to z pewnością wszyscy osadzeni będący rodzicami małoletnich, ale czy krąg uprawnionych należy zawęzić wyłącznie do osób sprawujących władzę rodzicielską, a jeśli tak, to czy ma ona mieć pełny zakres, czy jednak uprawnienie dotyczy także przypadków jej sądowego ograniczenia (na przykład poprzez umieszczenie dziecka w pieczy zastępczej)? Jednocześnie jeżeli podążać tropem interpretacji „stałej pieczy” przy wykorzystaniu instytucji prawa rodzinnego, jaką jest władza rodzicielska, pojawia się sprzeczność polegająca na identyfikacji kontaktów z dzieckiem (widzenia są przecież formą bezpośrednich kontaktów) ze skazanymi posiadającymi rodzicielskie prerogatywy, co z kolei przeczy zapisom art. 113 $\S 1$ k.r.o. Dodatkowo pod adresem $\S 3$ można postawić zarzut dyskryminacji, albowiem daje on prawo do dodatkowego widzenia wyłącznie tym osadzonym, którzy ową stałą pieczę sprawują nad dzieckiem w wieku do lat 15. Można pokusić się o zadanie pytania: jakie jest uzasadnienie dla przyjęcia tak sztywnej cezury wieku dziecka? Czy wynika ona ze znajomości prawidłowości psychologii rozwojowej, wskazującej, że po przekroczeniu 15 lat potrzeba bliskiego kontaktu dziecka z rodzicem słabnie? Czy może ustawodawca w przepisach wykonawczych przyjmuje, że wykonywanie pieczy nad dzieckiem ulega jakościowej modyfikacji właśnie w tym momencie i autorytarnie odbiera cenną z punktu widzenia młodego człowieka (być może dopiero wówczas emocjonalnie gotowego) przestrzeń do bycia $\mathrm{z}$ rodzicem? ${ }^{40}$

${ }^{40} \mathrm{Na}$ trudności w znalezieniu racjonalnego uzasadnienia ograniczenia wieku, do którego dzieci mogą korzystać z preferencji dodatkowego widzenia rodzica w toku odbywania przez niego kary pozbawienia wolności, zwrócił uwagę A. Kwieciński, op. cit., s. 196-197. Z kolei o psychologicznych uwarunkowaniach osadzenia rodzica (między 


\section{Kontakty osadzonych ojców z dziećmi w praktyce penitencjarnej}

Podstawą realizowania kontaktów osadzonych ojców z dziećmi są przepisy prawa, które zostały ukazane w poprzedniej części artykułu. Przepisy (poza powołaniem Domów Matki i Dziecka przy Zakładzie Karnym nr 1 w Grudziądzu oraz przy Zakładzie Karnym w Krzywańcu) nie różnicują rodziców ze względu na płeć. Te same warunki podtrzymywania kontaktów dotyczą uwięzionych matek oraz osadzonych ojców.

Jedną z form oddziaływania na osoby pozbawione wolności są programy penitencjarne realizowane przez funkcjonariuszy Służby Więziennej i inne upoważnione do tego podmioty. Programy te kierowane są do grup skazanych specyficznych ze względu na określone kryteria, w tym do rodziców i — szczególnie - ojców. Przykładem programu realizowanego przez funkcjonariuszy Służby Więziennej jest program „Ojciec przyjacielem dziecka" realizowany w Areszcie Śledczym w Grójcu ${ }^{41}$, w którym do ważniejszych celów należy zaliczyć motywowanie do systematycznego kontaktu z dziećmi, zapoznanie z podstawowymi prawidłowościami rozwoju psychicznego dziecka oraz prezentowanie możliwości spędzania czasu z dzieckiem.

Zajęcia dla ojców prowadzone są także przez instytucje spoza wymiaru sprawiedliwości. Jedną z nich jest Małopolskie Stowarzyszenie Probacja, które realizuje projekty: „KONTAKT — czyli jak być lepszym rodzicem zza krat” oraz „Poczytaj mi..., czyli osadzeni rodzice nagrywają bajki swoim dzieciom"42. Oba projekty, opierając się na aktualnej wiedzy psychologicznej i w nawiązaniu do indywidualnych doświadczeń uwięzionych rodziców, realizują cel, jakim jest podtrzymanie relacji rodzic-dziecko.

Programy, w których biorą udział ojcowie, czy to realizowane przez funkcjonariuszy Służby Więziennej, czy też poprzez organizacje spoza wymiaru sprawiedliwości, są z założenia dla rodziców. Można wyod-

innymi w kontekście sytuacji emocjonalnej ich dzieci i trudności w pogodzeniu się z faktem uwięzienia) pisze A. Domżalska, op . cit., s. 217-220 i literatura tam wskazana.

41 M. Marczak, Resocjalizacyjne programy penitencjarne realizowane przez Stużbe Więzienna w Polsce, Kraków 2009, s. 49-51.

42 www.probacja.org (dostęp: 1.10.2019). 
rębnić zajęcia wyłącznie dla ojców - mężczyzn, choć bywa i tak, że są przygotowywane $\mathrm{z}$ uwagi na realizowanie ich $\mathrm{w}$ jednostkach penitencjarnych dla mężczyzn lub w odpowiedzi na potrzeby wynikające z obserwacji relacji skazany mężczyzna-dziecko przez więzienników w konkretnym zakładzie karnym. Niestety w literaturze przedmiotu specyfika więziennego ojcostwa nie została jeszcze w wyczerpujący sposób opisana i trudno stwierdzić, jakie są szczególne potrzeby uwięzionych ojców w zakresie kontaktu z dziećmi. Dlatego też wiele programów ukierunkowanych jest na podnoszenie umiejętności rodzicielskich osób pozbawionych wolności, a nie ojców w szczególności (z przenoszonymi przez mężczyzn wzorami postępowania, reakcjami emocjonalnymi czy zachowaniami społecznymi). Każdy z tych programów jednak koncentruje swoje cele na podtrzymywaniu więzi z dziećmi poprzez spotkania rodzinne, nabywanie nowych umiejętności przez skazanych czy podejmowanie działań na rzecz własnych dzieci, tak aby zwiększyć liczbę kontaktów między ojcem a jego dziećmi.

\section{Zakończenie}

Bardzo trafne jest twierdzenie, że

kontakty z dzieckiem są konieczne nie tylko w celu wykonywania obowiązków rodzicielskich, ale potrzeba ich utrzymywania wynika z uczuciowej bliskości rodziców i ich dziecka. Nawet w razie utraty władzy rodzicielskiej rodzice i dziecko mają prawo do bliskiej więzi ze sobą; $[\ldots]$ to zjawisko natury emocjonalnej $[\ldots]^{43}$.

Takie stanowisko - które można sprowadzić do ogólnej tezy, że kontakty z dzieckiem są uprawnieniem rodzinnoprawnym wynikającym z faktu najbliższego pokrewieństwa - w wielu orzeczeniach reprezentują też Sąd Najwyższy ${ }^{44}$ oraz Europejski Trybunał Praw Człowieka ${ }^{45}$. Zdaniem Trybunału

43 T. Smyczyński, Prawo rodzinne i opiekuńcze, Warszawa 2018, s. 296.

44 Postanowienie SN z dnia 7 listopada 2000 roku, I CKN 1115/00, OSP 2001, nr 7-8, poz. 114; uchwała SN z dnia 14 czerwca 1988 roku, III CZP 42/88, OSNCP 1989, nr 10, poz. 156; wyrok SN z dnia 8 września 2004 roku, IV CK 615/03, MoP 2004, nr 19.

45 Wyrok ETPC z dnia 10 stycznia 2017 roku, 32407/13, Legalis 1555850; wyrok ETPC z dnia 28 czerwca 2016 roku, 28623/12, Legalis 1469102. 
interes dziecka wymaga ochrony jego rozwoju oraz więzi z jego rodziną, a zwłaszcza z jego matką i ojcem. Co do zasady, w najlepszym interesie dziecka leży podtrzymanie kontaktu z obojgiem z rodziców, w praktyce, na równych prawach, z wyjątkiem prawnych ograniczeń uzasadnionych przez kwestie związane z najlepszym interesem dziecka ${ }^{46}$.

Odbywanie przez rodzica kary pozbawienia wolności nie jest a priori okolicznością godzącą w dobro dziecka w związku z kontaktami ${ }^{47}$ i nie stanowi podstawy odebrania tego prawa. Z uwagi jednak na fakt izolowania rodzica realizacja osobistej styczności napotyka istotne ograniczenia. Wynikają one ze specyfiki funkcjonowania systemu penitencjarnego, zwłaszcza zaś z regulujących ten system norm prawa karnego wykonawczego. Analiza przepisów k.k.w. wskazuje, że zagadnienie kontaktu osadzonych z bliskimi jest podejmowane, jednak przede wszystkim z racji jego walorów resocjalizacyjnych oraz readaptacyjnych ${ }^{48}$. W sposób marginalny uregulowane zostały — jako szczególna kategoria — kontakty skazanych z dziećmi w formie widzeń. Nieprecyzyjny i ekskluzywny charakter istniejących unormowań (art. 87a oraz 105a) świadczy jednak o braku refleksji ustawodawcy nad sposobem skutecznego zabezpieczenia z jednej strony dobra dziecka, z drugiej — prawa osadzonego rodzica do realizacji fundamentalnego prawa do ochrony życia rodzinnego, będącego zarazem jedną z podstawowych potrzeb człowieka.

\section{Bibliografia}

\section{Literatura}

Andrzejewski M., Standardy opiniowania psychologicznego w sprawach rodzinnych i opiekuńczych - komentarz prawny, [w:] Standardy opiniowania psychologicznego w sprawach rodzinnych i opiekuńczych, red. A. Czerederecka, Kraków 2016.

Badowska-Hodyr M., Rodzice i ich dzieci w przestrzeni penitencjarnej z perspektywy zasad indywidualizacji oraz procesu reintegracji społecznej, „Probacja” 2018, nr 1.

46 Teza nr 1 do wyroku ETPC z dnia 10 stycznia 2017 roku.

47 Por. T. Justyński, Prawo do kontaktów z dzieckiem w prawie polskim i obcym, Warszawa 2011, s. 191. Inaczej należy ocenić sytuację odbywania kary za przestępstwo popełnione w związku z naruszeniem dobra dziecka lub drugiego z jego rodziców.

48 Wynika to bezpośrednio z brzmienia art. 67 § 3 k.k.w., § 50 RegWykKPWR, $\S 41$ rozporządzenia Ministra Sprawiedliwości z dnia 13 czerwca 2016 roku w sprawie sposobu i trybu wykonywania czynności przez kuratorów sądowych w sprawach karnych wykonawczych (Dz.U. z 2016 r. poz. 969). 
Chańko-Kraszewska A., Rodzina w percepcji i ocenie osób odbywających kare pozbawienia wolności, „Resocjalizacja Polska” 2018, nr 15.

Czerederecka A., Rozstrzyganie o kwestiach zwiazanych ze sprawowaniem władzy rodzicielskiej i uregulowaniem kontaktów z dziećmi - refleksje psychologa, „Rodzina i Prawo" 2013, nr 26-27.

Domżalska A., Dzieci rodziców pozbawionych wolności, „Forum Pedagogiczne UKW” 2011, nr 1.

Gałakan-Halicka A., Kontakty $z$ dzieckiem $w$ świetle nowelizacji kodeksu rodzinnego i opiekuńczego z 6 listopada 2008 r., [w:] Kodeks rodzinny i opiekuńczy po nowelizacji, red. J. Mazurkiewicz, Wrocław 2010.

Hryniewicz-Lach E., Komentarz do art. 37, [w:] Kodeks karny. Część ogólna. Komentarz do artykutów 1-116, red. M. Królikowski, R. Zawłocki, Lex/el 2017.

Ignaczewski J., Komentarz do spraw o kontakty z dzieckiem i o ich wykonanie, [w:] Komentarz do spraw rodzinnych, red. J. Ignaczewski, Warszawa 2014.

Ignatowicz J., [w:] System prawa rodzinnego i opiekuńczego, red. J.S. Piątkowski, Wrocław 1985.

Ignatowicz J., Nazar M., Prawo rodzinne, Warszawa 2005.

Justyński T., Prawo do kontaktów z dzieckiem w prawie polskim i obcym, Warszawa 2011.

Kilińska-Pękacz A., Prawo rodziców osób osadzonych do opieki $i$ wychowania dzieci, „Przegląd Więziennictwa Polskiego” 2018, nr 99.

Kwieciński A., Skazani-rodzice. Sytuacja prawna osadzonych sprawujacych opiekę nad dziećmi, „Nowa Kodyfikacja Prawa Karnego” 28, 2012.

Lachowski J., Komentarz do art. 100, [w:] Kodeks karny wykonawczy. Komentarz, red. J. Lachowski, Warszawa 2018.

Lelental S., Kodeks karny wykonawczy. Komentarz, Warszawa 2017.

Marczak M., Resocjalizacyjne programy penitencjarne realizowane przez Stużbę Więzienna w Polsce, Kraków 2009.

Safjan M., Osamotnione dzieci. Rodziny zastępcze i rodzinne domy dziecka, Warszawa 1983. Schulz A.N., Kontakty z dzieckiem, kontakty dziecka - nowelizacja kodeksu rodzinnego i opiekuńczego w świetle standardów europejskich, [w:] Kodeks rodzinny i opiekuńczy po nowelizacji, red. J. Mazurkiewicz, Wrocław 2010.

Smyczyński T., Prawo rodzinne i opiekuńcze, Warszawa 1997, 2018.

Sokołowski I., Charakter prawny osobistej styczności rodziców z dzieckiem, „Kwartalnik Prawa Prywatnego" 2000, z. 2.

Stojanowska W., Rozwód a dobro dziecka, Warszawa 1979.

Szczygieł G.B., Komentarz do rozdziału I § 4, [w:] System Prawa Karnego, t. 6. Kary i inne środki reakcji prawnokarnej, red. M. Melezini, Warszawa 2016.

Waligóra B., Funkcjonowanie człowieka w warunkach izolacji więziennej, Poznań 1974.

\section{Akty prawne}

Konwencja o prawach dziecka przyjęta przez Zgromadzenie Ogólne Narodów Zjednoczonych dnia 20 listopada 1989 roku (Dz.U. z 1991 r. Nr 120, poz. 526). 
Konwencja w sprawie kontaktów z dziećmi - Konwencja z dnia 15 maja 2003 roku, sporządzona w Strasburgu, ww2.senat.pl/k7/dok/sejm/021/895.pdf.

Rozporządzenie Ministra Sprawiedliwości z dnia 18 grudnia 2013 roku w sprawie sposobu przesłuchania przeprowadzanego w trybie określonym w art. 185a-185c Kodeksu postępowania karnego (Dz.U. z 2013 r. poz. 1642).

Rozporządzenie Ministra Sprawiedliwości z dnia 21 grudnia 2016 roku w sprawie regulaminu organizacyjno-porządkowego wykonywania kary pozbawienia wolności (Dz.U. z 2016 r. poz. 2231).

Rozporządzenie Rady Ministrów z dnia 4 sierpnia 2010 roku w sprawie szczegółowego trybu działań funkcjonariuszy Służby Więziennej podczas wykonywania czynności służbowych (Dz.U. z 2010 r. Nr 147, poz. 984).

Ustawa z dnia 25 lutego 1964 roku — Kodeks rodzinny i opiekuńczy (Dz.U. z 2012 r. poz. 788 ze zm.).

Ustawa z dnia 17 listopada 1964 roku Kodeks postępowania cywilnego (tekst jedn. Dz.U. z 2016 r. poz. 1822 z późn. zm.).

Ustawa z dnia 6 czerwca 1997 roku — Kodeks karny wykonawczy (Dz.U. z 2019 r. poz. 676 ze zm.).

Ustawa z dnia 6 czerwca 1997 roku Kodeks postępowania karnego (Dz.U. z 2018 r. poz. 1987 ze zm.).

Ustawa z dnia 6 listopada 2008 roku o zmianie ustawy — Kodeks rodzinny i opiekuńczy oraz niektórych innych ustaw (Dz.U. z 2008 r. Nr 220, poz. 1431).

Ustawa z dnia 5 sierpnia 2015 roku o opiniodawczych zespołach sądowych specjalistów (Dz.U. z 2018 r. poz. 708).

\section{Orzecznictwo}

Postanowienie SN z dnia 7 listopada 2000 roku, I CKN 1115/00, OSP 2001, nr 7-8, poz. 114.

Uchwała Pełnego Składu Izby Cywilnej Sądu Najwyższego z dnia 18 marca 1968 roku, III CZP 70/66, OSNCP 1968, z. 5, poz. 77.

Uchwała SN z dnia 14 czerwca 1988 roku, III CZP 42/88, OSNCP 1989, nr 10, poz. 156. Wyrok SN z dnia 8 września 2004 roku, IV CK 615/03, MoP 2004, nr 19.

Wyrok SA w Warszawie z dnia 20 października 2016 roku, VIACa 1245/15, Legalis 1618005. Wyrok ETPC z dnia 28 czerwca 2016 roku, 28623/12, Legalis 1469102.

Wyrok ETPC z dnia 10 stycznia 2017 roku, 32407/13, Legalis 1555850.

\section{Źródła internetowe}

www.probacja.org.

www.sw.gov.pl. 


\title{
Psychological and legal aspects of contacts between incarcerated fathers and their children
}

\begin{abstract}
Summary
The institution of parent-child contact is a parental right, characterized by a variety of forms of its implementation. It is to be, in addition to constitutional provisions, a normative guarantee for the protection of family ties and family life, regardless of the nature of the relationship between the child's parents, their parental attributes, and their place of residence. One of the circumstances that can affect the quality of contacts in a special way is the fact that a parent is detained in prison. Therefore, the question arises as to the shape of the provisions of the executive criminal law and the actual activities undertaken in the penitentiary, aimed at protecting such family relations.
\end{abstract}

Keywords: contacts with child, imprisoned person, prison, incarcerated parent, father. 